\title{
鋼種が異なるせん断型パネルダンパーの静的履歴特性に関する実験研究 \\ AN EXPERIMENTAL STUDY ON HYSTERETIC PERFORMANCE OF SHEAR PANEL DAMPERS USING DIFFERENT STRENGTH TYPE OF STEEL UNDER STATIC LOADING
}

\author{
田中 清*, 佐々木 康人**, 米山 真一朗** \\ Kiyoshi TANAKA, Yasuhito SASAKI and Shin-ichiro YONEYAMA
}

In the previous studies, hysteretic performance of the damper of shear panel type using low-yield-strength (LYP) steel, which has about $100 \mathrm{~N} / \mathrm{mm}^{2}$ of yield strength, under static shear loading were verified through cyclic loading tests. Other strength types of steel also have been utilized for panel damper. In this study, three different strength types of steel: two types of LYP steel (LYP100, LYP235) and normal mild steel (SS400), are selected for shear panel of the damper. Six specimens of square panel, whose width-thickness ratios are 22,33 and 50 respectively, were tested under static and cyclic shear loading without axial force. As the results of the test, specimens of lower strength type of steel that also had smaller yield strength ratio showed higher energy dissipating capacity. In consequence, it is understood that hysteretic performance of the panel damper with different strength type of steel, such as maximum strength, permissible deformation capacity and hysteresis rule, are well estimated by the empirical formula obtained from the previous studies on LYP100 steel panel dampers.

Keywords: $\quad$ Low-yield-strength steel, Normal mild steel, Hysteretic damper, Shear panel, Static loading test, Width-thickness ratio, Yield strength ratio, Hysteresis model 低降伏点鋼, 普通強度鋼, 履歴型ダンパー, せん断パネル, 静的加力実験, 幅厚比, 降伏比, 履歴モデル

\section{1.はじめに}

せん断パネル型の履歴ダンパーは、シヤパネルと周辺の枠フラン ジにより構成され、柱、梁よりなる骨組構面に各種の支持部材を介 して取付けられる。パネルの鈆直高さは階高に対し 1/3〜1/10 程度 のものが使用されている。この高さ比(パネル高さ比)が小さいもの ほど、層間変形角に対しパネル変形角が増幅され、パネルには大き な塑性変形能力が要求される。

せん断パネル型の鋼製履歴ダンパーの研究開発·実用化状況を見る

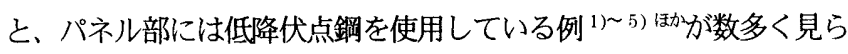
れるが、普通強度鋼の研究例 4) 6) も見られる。低降伏点鋼 7)には、 降伏点が約 $100 \mathrm{~N} / \mathrm{mm}^{2}$ と約 $235 \mathrm{~N} / \mathrm{mm}^{2}$ の 2 種類の鋼種が使用されており、 降伏点が約 $100 \mathrm{~N} / \mathrm{mm}^{2}$ の鋼種は極低降伏点鋼または極軟鋼と呼ばれて いる。また、普通強度鋼が使用される例では SS400 とSM490 の 2 種 類が使用されている。低降伏点鋼は、履歴ダンパー用鋼材として開 発・市販されている鋼材であるが、現時点では、J I S 規格外品で あり、普通強度鋼とは法規上の扱いを異にしている。

既報 ${ }^{8)}$ では、パネル高さ比が数分の 1 1/10 程度を想定した極低 降伏点鋼を用いた無補剛正方形せん断パネルと補剛りブ付き長方形 せん断パネルを対象とし、幅厚比を変数として、軸力がゼロのもと
での静的せん断力下における繰返し履歴特性について実験的に検討 した。その結果、ダンパーとしての有用性を示すとともに、設計上 必要となる履歴性能指標(最大耐力、性能保証限界累積せ九断变形角) を提示し、降伏ひずタと降伏比で規準化した幅厚比(換算幅厚比 ${ }^{8)}$ ) を用いることにより、性能予測を精度良く行えることを示した。ま た併せて、適合性の良い履歴モデル(スケルトン・シフト・モデル ${ }^{10)}$ ) に用いるスケルトン曲線を提示した。

本研究では、既報と同様にパネル高さ比を数分の 1 ～1/10 程度に 想定し、変形能力が要求されるせん断型パネルダンパーの基本型と 位置づけている無補剛正方形パネルを対象とする。またパネル部に 使用する鋼種として 2 種類の低降伏点鋼( LYP100,LYP235) と普通強 度鋼として SS400 を選定し、軸力ゼロ下での静的せん断実験により 各パネルの履歴特性を比較し、本研究で対象とする变形性能要求レ ベルに対する適合性を検討することを目的としている。また、既報 で提案した性能評価法が、他の鋼種のパネルダンパーに対してどの 程度の適合性を有するかを併せて検討する。さらに、設計上重要と なる最大耐力時におけるパネルと枠フランジのせん断力負担状況、 性能保証限界累積せん断変形時でのパネルの面外変形状況、および 履歷特性のモデル化に関する検討を行うものである。

\footnotetext{
本論文は，文献9)に加筆・修正を行ったものである。

* (侏フブタ技術研究所主席研究貣・博士 (工学)

**侏フジ夕技術研究所 研究員・エ修
}

Head Research Engineer, Technology Research Institute, Fujita Corporation, Dr. Eng.

Research Engineer, Technology Research Institute, Fujita Corporation, M. Eng. 


\section{2. 静的加力実験}

\section{1 試唉体}

試験体は、枠フランジ付き無補剛の正方形パネルダンパー（以下、 パネルダンパー）で、その一覧を表 1 に、形状・寸法例を図 1 に示 す。試験体数は合計 6 体である。本実験で対象とするパネルダンパ 一は、その高さが階高の数分の 1 から $1 / 10$ 程度のものを対象として いる。試験体の溶接は、エンドプレートと枠フランジとを突合わせ 溶接とし、パネルとエンドプレートおよび枠フランジとはすみ肉溶 接(サイズ : パネル厚と同じ) とした。すみ肉溶接の溶接条件を図 1 中に示す。

表 1 試験体諸元の一覧

\begin{tabular}{|c|c|c|c|c|c|c|}
\hline 試験体名 & L100-33 & L100-50 & L235-22 & L235-33 & L235-50 & S400-33 \\
\hline パネル部銅種 & LYP100 & LYP100 & LYP235 & LYP235 & LYP235 & SS400 \\
\hline $\mathrm{d}(\mathrm{mm})$ & 300 & 300 & 200 & 300 & 300 & 300 \\
\hline $\mathrm{t}_{\mathrm{w}}(\mathrm{mm})$ & 9 & 6 & 9 & 9 & 6 & 9 \\
\hline 幅厚比 $\left(\mathrm{d} / \mathrm{t}_{\mathrm{w}}\right)$ & 33.3 & 50.0 & 22.2 & 33.3 & 50.0 & 33.3 \\
\hline 換算幅厚比 $\left(\mathrm{d} / \mathrm{t}_{\mathrm{w}}\right)_{\mathrm{B}}^{*}$ & 1.16 & 1.81 & 0.89 & 1.33 & 2.04 & 1.52 \\
\hline
\end{tabular}
（注）枠フランジ板厚,板幅, 鋼種は同一のものを使用

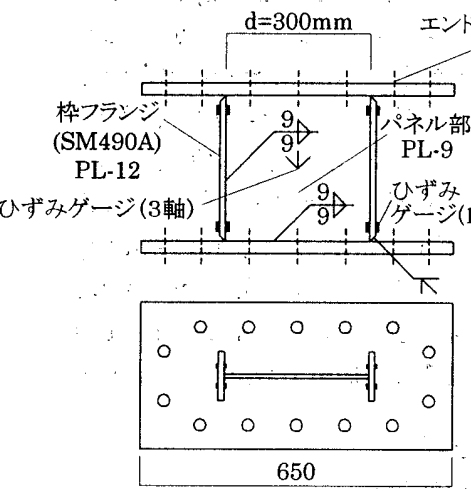

$$
\text { エンドプレート(SM490A) PL-25 }
$$
*式(1)による

図 1 試験体の形状・寸法例 $\left(\mathrm{d} / \mathrm{t}_{\mathrm{w}}=33.3\right.$ の試験体 $)$

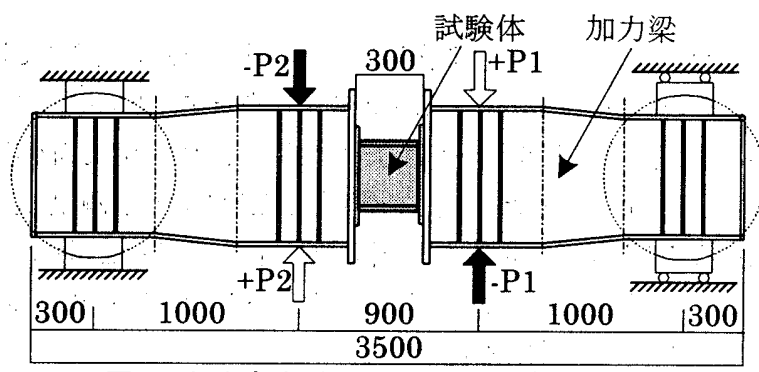

図 2 加力方法 $(\mathrm{d}=300 \mathrm{~mm}$ の試験体の例 $)$
実験変数はパネル部の鋼種と幅厚比である。鋼種は、極低降伏点 鎆（BT-LYP100）、低降伏点鍓（BT-LYP235）、および普通強度 鋼（ SS400）の3種とした。幅厚比は、22、33 および 50 の3 種と した。使用した鋼材の素材試験結果を表 2 に示す。

\section{2 実験力法}

パネルダンパー試験体の両側に鋼製の加力梁を高力ボルト接合し て梁型の試験部を製作し、図 2 に示す大野式曲げせん断加力法に準 じて、パネルダンパー試験体にせん断力を正負交番繰返し載荷した。 加力に際しては、試験体の上下エンドプレートが平行に変形するよ うに荷重 $\left(\mathrm{P}_{1}, \mathrm{P}_{2}\right)$ を調整しかつ加力点近傍の加力梁を面外变形拘

表 2 使用鋼材の素材試験結果

\begin{tabular}{|c|c|c|c|c|c|c|}
\hline 鋼種 & $\begin{array}{c}\text { 板厚(実測值) } \\
\mathrm{t}(\mathrm{mm})\end{array}$ & $\begin{array}{c}\text { 降伏点 } \\
\mathrm{\sigma}_{\mathrm{y}}\left(\mathrm{tf} / \mathrm{cm}^{2}\right)\end{array}$ & $\begin{array}{c}\text { 引張強さ } \\
\mathrm{\sigma}_{\mathrm{B}}\left(\mathrm{tf} / \mathrm{cm}^{2}\right)\end{array}$ & 降伏比 & $\begin{array}{c}\text { 伸び } \\
(\%)\end{array}$ & 使用部位 \\
\hline BT-LYP100 & $6(6.2)$ & $0.86^{*}$ & 2.74 & 0.31 & 56.5 & $\mathrm{~L} 100-50$ パネル \\
\hline BT-LYP235 & $9(9.0)$ & $0.87^{\star}$ & 2.56 & 0.34 & 60.1 & L100-33パネル \\
\hline SS400 & $9(5.7)$ & 2.39 & 3.48 & 0.69 & 46.7 & L235-50パネル \\
\hline SM490A & $9(8.7)$ & 2.30 & 3.36 & 0.68 & 52.3 & L235-22,33パネル \\
\hline
\end{tabular}
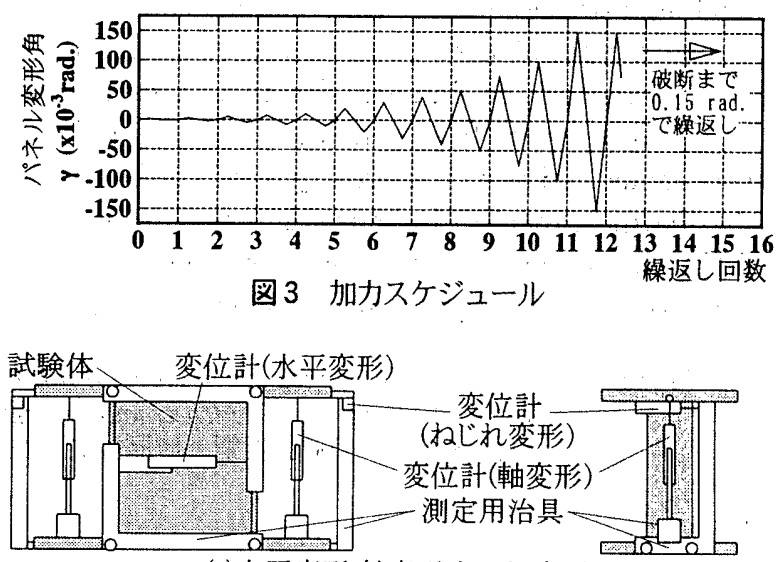

(a)水平変形,軸変形,ねじれ変形

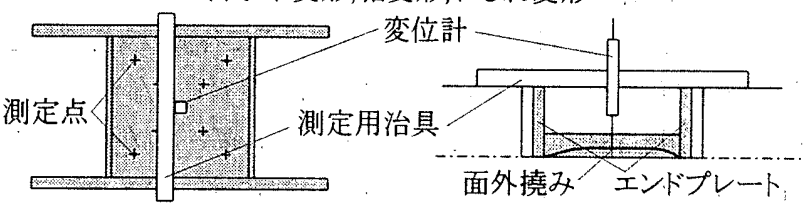

(b)面外撓み (各サイクルのピーク時に測定)

図4 変形の測定方法

表 3 主要な実験結果の一覧

\begin{tabular}{|c|c|c|c|c|c|c|c|c|c|c|c|c|c|c|c|c|}
\hline \multirow[b]{2}{*}{ 試験体 } & \multirow[b]{2}{*}{$\begin{array}{l}\text { 加力 } \\
\text { 方向 }\end{array}$} & \multirow{2}{*}{$\begin{array}{c}\text { 弾性係数 } \\
\mathrm{G} \\
\left(\mathrm{tf} / \mathrm{cm}^{2}\right)\end{array}$} & \multicolumn{3}{|c|}{ 降伏荷重時 } & \multicolumn{4}{|c|}{ 最大荷重時 } & \multicolumn{3}{|c|}{ 性能保証限界変形時 * } & \multicolumn{3}{|c|}{ 亀裂発生時 } & \multirow[b]{2}{*}{ 破壊形式 } \\
\hline & & & $\begin{array}{l}Q_{y} \\
(t f) \\
\end{array}$ & $\begin{array}{c}\tau_{\mathrm{wy}} \\
\left(\mathrm{tf} / \mathrm{cm}^{2}\right)\end{array}$ & $\begin{array}{c}\gamma_{\mathrm{y}} \\
\left(\times 10^{-3} \mathrm{rad} .\right)\end{array}$ & $\begin{array}{l}\mathrm{Q}_{\mathrm{B}} \\
(\mathrm{tf}) \\
\end{array}$ & $\begin{array}{c}\tau_{\mathrm{wB}} \\
\left(\mathrm{tf} / \mathrm{cm}^{2}\right)\end{array}$ & $\begin{array}{c}\tau_{\mathrm{pu}} \\
\left(\mathrm{tf} / \mathrm{cm}^{2}\right)\end{array}$ & $\begin{array}{c}{ }^{\gamma_{B}} \\
\text { (rad.) }\end{array}$ & $\begin{array}{l}Q_{1} \\
(t f) \\
\end{array}$ & $\begin{array}{c}\tau_{\mathrm{wl}} \\
\left(\mathrm{tf} / \mathrm{cm}^{2}\right)\end{array}$ & $\begin{array}{c}{ }^{\gamma} \gamma_{u} \\
\text { (rad.) }\end{array}$ & $\begin{array}{r}Q_{c} \\
(t f)\end{array}$ & $\begin{array}{c}\tau_{w c} \\
\left(\mathrm{t} f / \mathrm{cm}^{2}\right)\end{array}$ & $\begin{array}{c}{ }^{\gamma_{c}} \\
\text { (rad.) }\end{array}$ & \\
\hline \multirow{2}{*}{ LiO0-33 } & + & 376.7 & 13.1 & 0.47 & 1.30 & 62.5 & 2.23 & 2.24 & 1.062 & 52.8 & 1.88 & 1.752 & 60.3 & 2.15 & 1.644 & \multirow{2}{*}{$\begin{array}{c}\mathrm{A} \rightarrow \mathrm{C} \rightarrow \mathrm{D} \\
\rightarrow \mathrm{B}\end{array}$} \\
\hline & - & 349.9 & 12.0 & 0.43 & 1.34 & 62.5 & 2.23 & 2.24 & 0.906 & 55.2 & 1.97 & 1.609 & $\ldots$ & ........ & & \\
\hline \multirow{2}{*}{ L100-50 } & + & 479.5 & 7.5 & 0.39 & 1.10 & 34.3 & 1.77 & 1.74 & 0.359 & 31.9 & 1.65 & 0.606 & 20.5 & 1.06 & 1.534 & \multirow{2}{*}{$\begin{array}{l}\mathrm{C} \rightarrow \mathrm{D} \rightarrow \mathrm{A} \\
\rightarrow \mathrm{E} \rightarrow \mathrm{F}\end{array}$} \\
\hline & - & 1335.7 & 4.0 & 0.21 & 0.20 & 35.2 & 1.82 & 1.79 & 0.405 & 33.1 & 1.71 & 0.517 & 34.3 & 1.78 & & \\
\hline \multirow{2}{*}{ L235-22 } & + & 1509.0 & 15.5 & 0.84 & 0.55 & 58.3 & 3.17 & 3.16 & 1.657 & 45.3 & 2.46 & 1.737 & 56.1 & 3.04 & 1.328 & \multirow{2}{*}{$A \rightarrow B$} \\
\hline & - & 1499.3 & 17.0 & 0.92 & 0.21 & 60.2 & 3.27 . & 3.27 & 1.508 & 38.1 & 2.07 & 1.901 & 58.1 & 3.16 & 1.508 & \\
\hline \multirow{2}{*}{ L235-33 } & t. & 491.7 & 29.6 & 1.09 & 2.68 & 70.6 & 2.60 & 2.63 & 0.769 & 67.7 & 2.50 & 0.932 & 40.0 & 1.48 & 1.071 & \multirow{2}{*}{$\begin{array}{c}\mathrm{C} \rightarrow \mathrm{A} \rightarrow \mathrm{D} \\
\rightarrow \mathrm{B}\end{array}$} \\
\hline & - & 660.2 & 25.8 & 0.95 & 1.10 & 69.1 & 2.55 & 2.57 & 0.850 & 69.1 & 2.55 & 0.853 & 52.9 & 1.95 & 1.331 & \\
\hline \multirow{2}{*}{ L235-50 } & + & 493.6 & 22.0 & 1.24 & 2.65 & 35.1 & 1.98 & 1.94 & 0.165 & 29.5 & 1.66 & $0.280^{\circ}$ & ........ & ...... & $\ldots$ & \multirow{2}{*}{$\begin{array}{c}\mathrm{C} \rightarrow \mathrm{D} \rightarrow \mathrm{E} \\
\rightarrow \mathrm{F}\end{array}$} \\
\hline & & .661 .8 & 18.4 & 1.04 & 1.74 & 38.6 & 2.17 & 2.14 & 0.198 & 34.5 & 1.94 & 0.225 & 33.2 & 1.87 & 1.837 & \\
\hline \multirow{2}{*}{$\mathrm{S} 400-33$} & + & 1070.8 & 31.1 & 1.16 & 0.98 & 81.5 & 3.04 & 3.08 & 0.689 & 81.3 & 3.03 & 0.689 & ......... & ….... & $\ldots . . .$. & \multirow{2}{*}{$\mathrm{C} \rightarrow \mathrm{A} \rightarrow \mathrm{B}$} \\
\hline & - & 1084.6 & 27.3 & 1.02 & 1.21 & 83.2 & 3.10 & 3.15 & 0.614 & 80.4 & 3.00 & 0.756 & 59.0 & 2.20 . & 0.899 & \\
\hline
\end{tabular}

-Q: せん断力, $\boldsymbol{\tau}$ : せん断応力度, $\gamma$ : せん断変形角, $\gamma$ : 累積せん断変形角

QQ : General-yield-point洼敒切算定

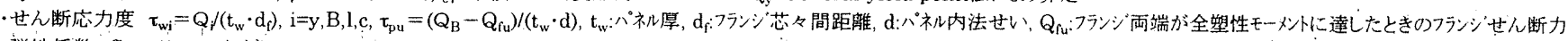

·弾性係数 $\mathrm{G}=\tau_{\mathrm{w}} /(\kappa \cdot \gamma)$ ただし $\kappa=1$

・性能保証限界変形時: せ九断座屈が明瞭となり、蕧歷曲線上で接線勾配がゼロとなる変形時

・破壊形式 A:才み肉溶接部近傍に亀裂発生, B:才み肉溶接部近傍の亀裂貫通, C:パネル座屈発生(目視により確認)，D:性能保証限界，E:パネル部亀裂発生，F:パネル部龟裂貫通 


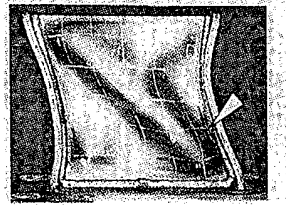

(a) L100-33 試験体

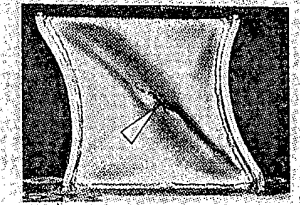

(b) $\mathrm{L} 100-50$ 試験体

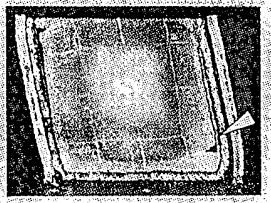

(c) L235-22 試験体

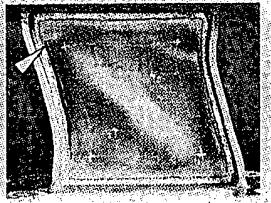

(d) L235-30 訌験体

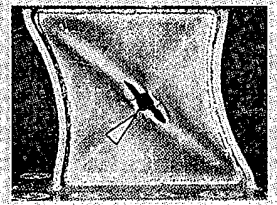

(e) L235-50 試験体

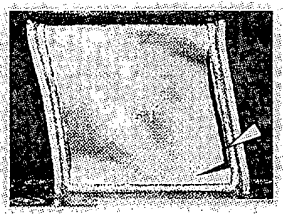

(f) $5400-33$ 試験体

写真 1 全試験体の最終変形状況 [白矢印は亀裂発生位置を示す］

[凡例 ]

実験值

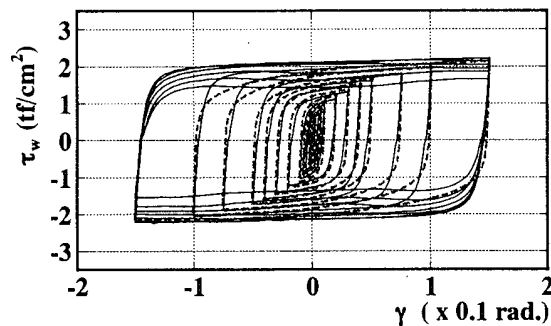

(a) L100-33試験体

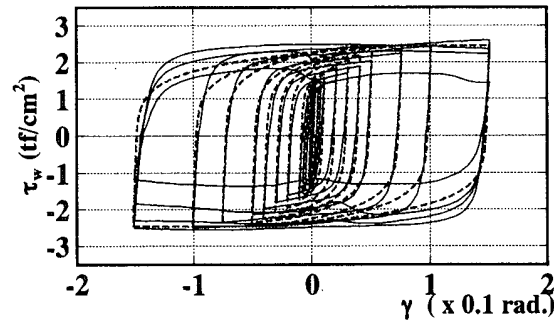

(d) L235-33試験体

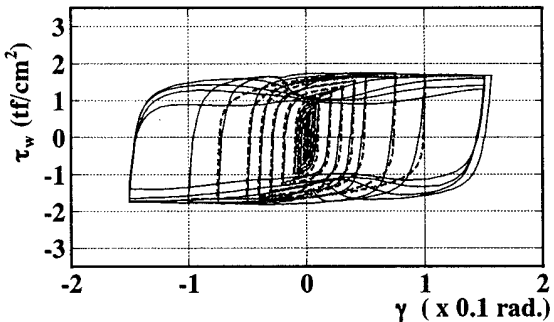

(b) $\mathrm{L} 100-50$ 試験体

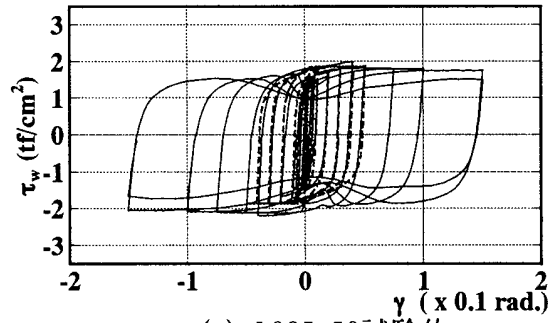

(e) L235-50試験体
計算值（性能保証限界变形点まで）

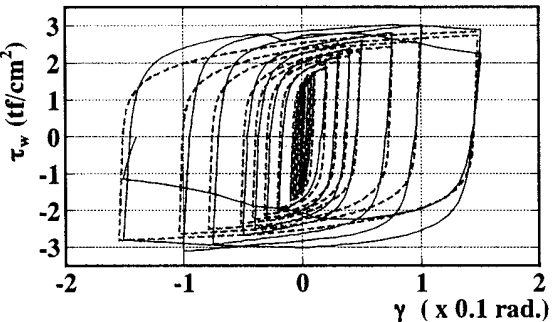

(c) L235-22試験体

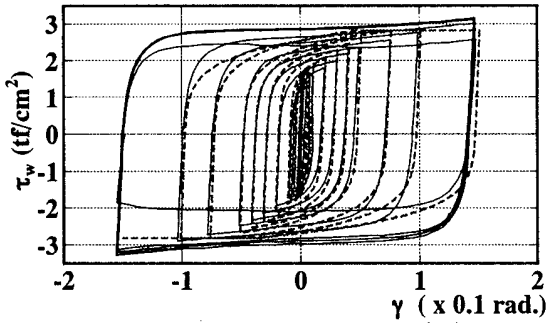

(f) S400-33試験体

図 5 平均せ九断応力度一せ九断変形角関係（実験值と計算值との比較）

束して、パネル部の変形制御により載荷を行った。加力スケジュー ルを図 3 に示す。荷重（ $\left.\mathrm{P}_{1}, \mathrm{P}_{2}\right)$ はロードセルにより測定し試験体 のせん断力 $\left\{10\left(\mathrm{P}_{1}+\mathrm{P}_{2}\right) / 29\right\}$ に換算した。各部の変形測定方法を図 4 に示すが、パネルの水平変形、軸变形、ねじれ变形を連続的に測 定した。パネルの面外撓み量は各加力サイクルの最大変形時に測定 した。またひずみゲージを、パネル中央部とフランジ両端部の表裏 に貼付し、表面ひずみを測定した。

\section{3. 実験結果}

主要な実験結果を一覧にして、表 3 に示す。なお、せん断応力度 には、表中にも示すように 2 種類の值を用いている。(1)履歴特性の 検討には、柱・梁接合部パネルの評価法に準じ、全水平荷重を枠フ ランジ芯々距離 $\left(\mathrm{d}_{\mathrm{f}}\right)$ とパネル厚 $\left(\mathrm{t}_{\mathrm{w}}\right)$ との積で除して求めた平 均せん断応力度 $\left(\tau_{\mathrm{w}}\right)$ を用い、(2)パネルの最大せん断応力度 $\left(\tau_{\mathrm{pu}}\right)$ には、枠フランジとパネルの材質が異なるため、パネル負担せん断 力をパネル内法せい $(\mathrm{d})$ とパネル厚との積で除した值を用いている。

\section{1 実験経過}

いずれの試験体も、ひずみゲージの測定結果より、パネル中央部 がまずせん断降伏し、続いて枠フランジ上下端が降伏した。パネル の初降伏は、降伏点の低い鋼種ほど小さな変形で生じた。変形の増 大に伴い、枠フランジ上下端近傍に塑性ヒンジを生じた。損傷過程 は以下の通りである。

LYP100 試験体では、最大荷重以降にパネル部の明瞭な座屈および すみ肉溶接部近傍母材に亀裂が発生した。幅厚比 33 の試験体では最 終的にすみ肉溶接部の亀裂が貫通したが、幅厚比 50 の試験体ではせ ん断座届の進展に伴いパネル中央部に曲げ亀裂が貫通した。

LYP235 試験体では、幅厚比 22 の試験体では明瞭な座屈は発生せ
ず、すみ肉溶接部近傍母材に亀裂が貫通した。他の 2 体は、LYP100 試験体とほぼ同様の損傷過程を示した。

SS400 試験体は最大荷重以降に、他の幅厚比が同じ試験体と同様 に、すみ肉溶接部に貫通亀裂が発生した。実験終了後におけるすべ ての試験体の変形状況を写真 1 に示す。

\section{2 荷重一変形関係}

試験体の荷重一変形関係を、平均せん断応力度 $\left(\tau_{w}\right)$-せん断変形 角 $(\gamma)$ 関係にして図 5に示す。また平均せん断応力度一累積せん断 変形角 $\left({ }_{\mathrm{c}} \gamma\right)$ 関係および平均せん断応力度一せん断変形角関係スケ ルトン曲線を図 6 に示す。スケルトン曲線は、加藤・秋山モデル ${ }^{11)}$ のスケルトン部に相当するものである。図 6 中には、最大荷重時と 後述する性能保証限界変形時を○と口印で示している。

平均せん断応力度は水平せん断力をパネル板厚と両側枠フランジ 芯々距離で除した值である。せん断変形角は上下エンドプレート間 の相対水平変形をパネル高さで除した值である。また文献 8）に示 すように、性能保証限界変形は履歴曲線上で接線勾配がゼロになり 以降局部的な耐力低下を示す時点の累積せん断変形としている。

各試験体とも、変形性能に富む履歴曲線を描いており、履歴ダン パーとしての適性が認められる。しかし、エネルギー消費能力の観 点からは、降伏点が低い（降伏比が小さい）鋼材を使用したパネ ルほど、また幅厚比が小さいものほど耐力低下が少なくより変形能 力に富む安定した履歴性状を示す結果となっている。この結果は、 既往の実験結果 ${ }^{31)}$ ５．8) と一致している。

幅厚比 33 の試験体を比較してみると、LYP235 とSS400 の試験体で は、最大荷重に達した直後に性能保証限界変形点に達しているが、 LYP100 の試験体では、最大荷重点の変形に対し約 2 倍の変形余裕を 有している。また、性能保証限界变形点以降の亀裂が貫通するまで 
の累積せん断変形角も大きくなっている。これは、亀裂発生後の耐 力低下が、LYP100,LYP235, SS400 の順に、緩やかであったことに対応 している。幅厚比 50 の試験体においては、LYP100 と LYP235 の比較 であるが、幅厚比 33 の試験体とほぼ同様な比較結果となっている。 また、幅厚比が最も小さい 22（LYP235）の試験体は、最大荷重時ま では他の試験体に比して、最も大きなエネルギ一消費性能を示すが、 パネルと枠フランジとのすみ肉溶接部が破断すると急激な耐力低下 を示した。

\section{3 履暦消費エネルギー}

荷重一変形曲線より求められる履歴消費エネルギーと累積せん断 変形角との関係を、鋼種、幅厚比ごとに比較して、図 7 に示す。な お、図中に示す履歴消費エネルギーは，枠フランジ芯々間距離にパネ ル厚を乗じた断面積で除し、単位面積当たりの值に変換している。

図7 (a)，(b)には、それぞれ LYP100 とLYP235について、幅厚比の 違いによる消費エネルギーの履歴を示している。鋼種が同じ場合に は、途中まではほぼ等しい勾配で履歴消費エネルギーは増加するが、 幅厚比が大きいものほど、途中から増加割合が低下してくる。これ は座屈の影響によるものである。

図7 (c)，(d)には、それぞれ幅厚比が 33 と50 の試験体について、 鋼種の違いによる比較を示している。幅厚比が同じで鋼種が異なる 場合には、変形が小さい領域では降伏点の高いものほど増加割合が高 い。しかし、変形が増大すると、降伏点が高いものほど明瞭な座届 に伴うエネルギー消費量の低下を生じている。結果的に，伸び能力 の最も大きいLYP100が 最も大きなエネルギ一消費量を示した。

\section{4. 既提案式による履歷性能の検讨}

文献 8)では、極低降伏点鋼を用いたパネルダンパーについて設計 上重要となる代表的な履歷性能指標である最大せん断耐力と性能保 証限界累積せん断変形角、および同様に重要となる履歴特性の評価 に必要なスケルトン曲線を取上げ、式(1)に示す換算幅厚比を用いる ことにより、各指標を精度良く予測できることを示した。なお換算 幅厚比は、降伏ひずみと降状比で規準化した幅厚比である。

本章では、パネルの鋼種が異なる場合に、上記の 3 つの指標を共 通の尺度で評価できるか否かについて検討する。また、本実験で明 らかとなつた各指標に対する補足的な性能評価結果も併せて示す。

\section{1 最大せん断㓦力}

パネルダンパーの最大せん断耐力は,パネルの負担せん断力と枠フ ランジの負担せん断力の和で表すことができる。

ここでは、パネルダンパーの最大せん断耐力にづいて、まず極低降 伏点鋼パネルダンパーに対して得られているパネルの最大せん断応 力度に関する実験式との適合性を検討する。次に、パネルダンパー の最大せん断耐力に寄与する枠フランジの負担せん断力について、 ひずみゲージの測定值を用いて幅厚比、鋼種別に検討する。

(1) 既提案式による評価 ( パネルの最大せん断応力度 )

表 3 に示すパネルの最大せん断応力度 $\left(\tau_{\mathrm{pu}}\right)$ は、表下に示すよ うに、最大荷重から枠フランジ上下端に塑性ヒンジを仮定したときの 負担せん断力（計算值）を差し引いた值を、パネル内法断面 積で除した值である。この值を $\tau_{\mathrm{B}}\left(=\sigma_{\mathrm{wB}} / \sqrt{3} 、 \sigma_{\mathrm{wB}}\right.$ はパネル鋼材 の引張強さ）で除した規準化最大せん断応力度（ $\left.\tau_{\text {pu }}{ }^{\prime}\right)$ に変換し、 式(1)に示す換算幅厚比 $\left\{\left(\mathrm{d} / \mathrm{t}_{\mathrm{w}}\right)_{\mathrm{B}}\right\}$ との関係を図 8 に示す。図中

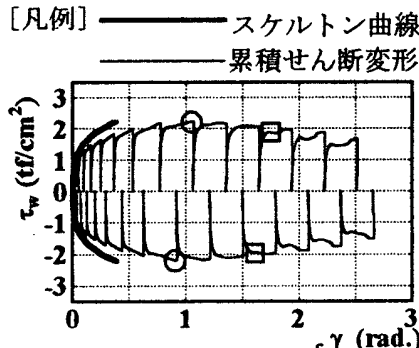

(a) L100-33試験体

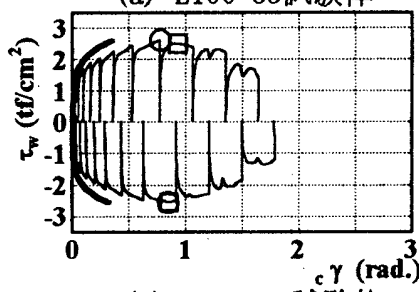

(c) L235-33試験体

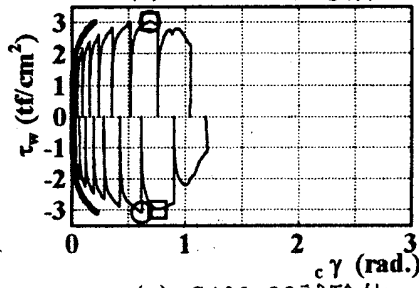

(e) S400-33試験体

図6 平均せん断応力度一累積せん断変形角関係

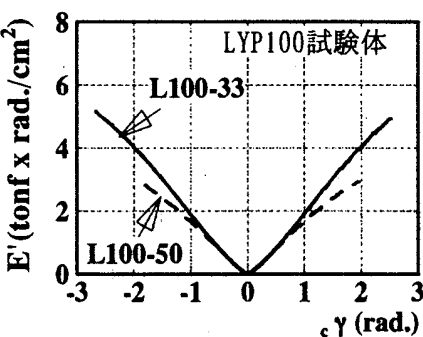

（a）幅厚比の違いによる比較

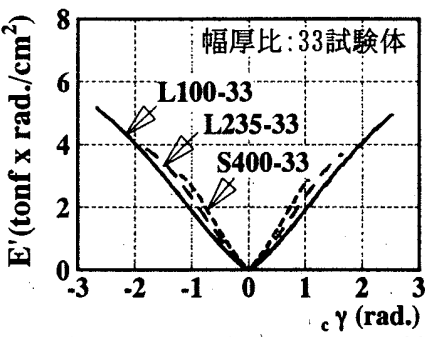

（c）鋼種の違いによる比較

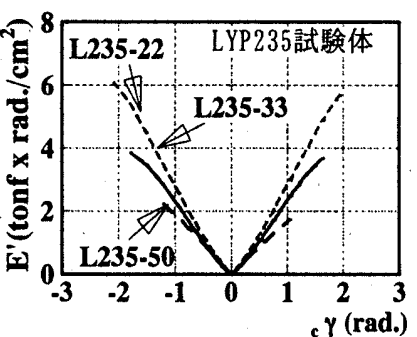

（b）幅厚比の違いによる比較

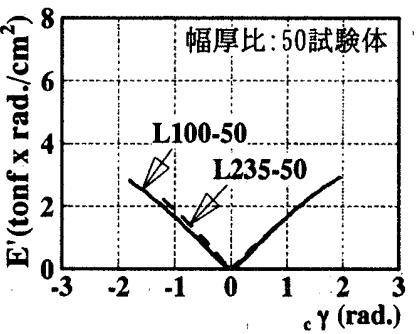

（d）鋼種の違いによる比較

図 7 パネル単位断面積当たりの消費エネルギーと 累積せん断変形角との関係

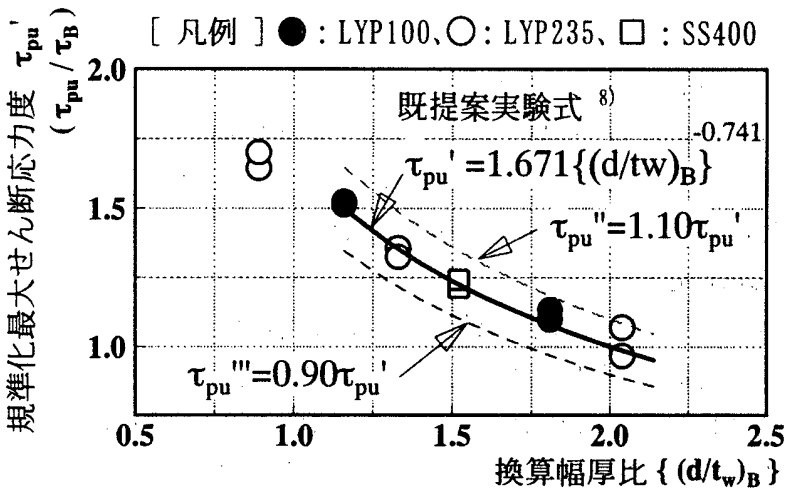

図8 規準化最大せん断応力度と換算幅厚比との関係 
の曲線式は文献 8)に示す極低降伏点鋼正方形パネルに関する実験式 である。本実験結果は、既実験式による結果とほぼ一致しており、 式(1)で表される換算幅厚比が、パネルの最大せん断応力度の有効な 評価変数であることが確認された。ただし、実験式の適用範囲は、1.16 $\leqq\left\{\left(\mathrm{d} / \mathrm{t}_{\mathrm{w}}\right)_{\mathrm{B}}\right\} \leqq 2.14$ であり、L235-22 試験体は適用範囲外の試 験体である。

$$
\left(d / t_{w}\right)_{B}=\left(d / t_{w}\right) \cdot \sqrt{\sigma_{w y} / E} \cdot \sqrt{\sigma_{w B} / \sigma_{w y}}
$$

ここで、 $\mathrm{d}$ : パネル内法せい、 $\mathrm{t}_{\mathrm{w}}$ : パネル厚、 $\sigma_{\mathrm{wy}}$ : パネルに使 用した鎆材の降伏点、 $\sigma_{\mathrm{wB}}$ : パネルに使用した鋼材の引張強さ、 $\mathrm{E}$ ： パネルに使用した鋼材のヤング係数 である。

\section{(2) 枠フランジ負担せん断力に対する考察}

図8に示すパネルの最大せん断応力度は、前記した $\tau_{\mathrm{B}}$ の值を大き く超える結果を与えている。この結果に対する明快な考察には未だ 到っていないが、最大せん断応力度算定に際して仮定した枠フラン ジ部の負担せん断力に対する検討を以下に行う。

ここでは、枠フランジ材の応力-ひずみ関係スケルトン曲線を素材 試験結果に基づきモデル化し、図 9 に示すように、枠フランジに貼 付したひずみゲージ測定值をもとに、繰返しを受ける塑性域での表 面応力を、Ramberg-0sgood モデルにより求め、ゲージ貼付け位置の 負担モ一メントと軸力を算定し、両者により負担される枠フランジせ ん断力の合力 $\left(\mathrm{Q}_{\mathrm{f}}\right)$ を求めた。算定に際し、以下の仮定を設けてい る。(1)フランジ断面内の中立軸位置が特定できないため、便宜的に、 枠フランジ断面内の応力分布は直線分布に仮定する。(2)枠フランジ の曲げモーメント分布は、パネルの面内力の影響により、線形分布 とはならないが、枠フランジ上下端のひずみ測定位置では、パネル 面内力による曲げモーメントはゼロであると仮定する。

計算結果の一例として、L100-33 試験体に関して、枠フランジの 曲げによる負担せん断力および軸力による負担せん断力とせん断変 形角の履歴曲線、同負担軸力と負担曲げモーメントとの相関関係の 計算結果例を図 $10(\mathrm{a}) \sim(\mathrm{c})$ に示す。また同様にして得られた各試験 体の枠フランジ負担せん断力の合力とせん断変形角との関係を図 11 に示す。両図中には、試験体の最大荷重時を○印で示している。

L100-33 試験体を取り上げて、枠フランジの応力負担状況を検討 した結果、枠フランジの曲げによる負担せん断力と軸力による負担 せん断力は、若干軸力による負担の方が大き目ではあるが、大略ほ ぼ等しい值を示している。また、枠フランジの軸力は、全体曲げに よる付加軸力を差し引くと、引張力となっている。この傾向は、幅 厚比が小さいほど明瞭となってきている。

次に、このようにして得られた枠フランジ負担せん断力とパネル のせん断変形角との関係を考察する。幅厚比 33 の試験体では、枠フ ランジ負担せん断力はほぼ前記した略算值である軸力ゼロ下におけ る全塑性モーメント時の負担せん断力と大略等しい。幅厚比が小さ くなると略算值よりも大きな值を示し、逆に幅厚比が大きくなると 略算值よりも小さな值を示した。

以上の結果より、枠フランジの負担せん断力は、大略軸力ゼロ下 における全塑性モーメント時の負担せん断力に等しく、パネル部の 最大せん断応力度が想定される保有せん断強度 $\left(\tau_{\mathrm{B}}\right)$ に対して大 幅に増大する実験結果に対する明瞭な考察は得られなかった。パネ ル部最大せん断応力度の評価方法については今後の課題とする。
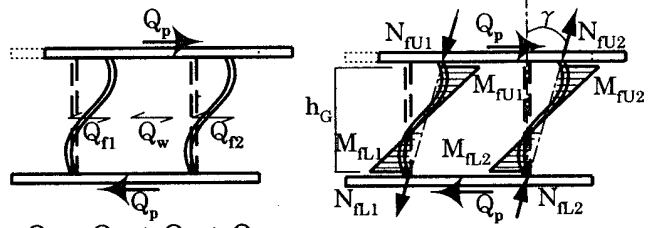

$\mathrm{Q}_{\mathrm{p}}=\mathrm{Q}_{\mathrm{f} 1}+\mathrm{Q}_{\mathrm{f} 2}+\mathrm{Q}_{\mathrm{w}}$
$\mathrm{Q}_{\mathrm{f} 1}+\mathrm{Q}_{\mathrm{f} 2}=\mathrm{Q}_{\mathrm{fM}}+\mathrm{Q}_{\mathrm{fN}}$

$\mathrm{Q}_{\mathrm{fM}}=\left(\mathrm{M}_{\mathrm{fU} 1}+\mathrm{M}_{\mathrm{fU} 2}-\mathrm{M}_{\mathrm{fL} 1}-\mathrm{M}_{\mathrm{fL} 2}\right) \cos \gamma / \mathrm{h}_{\mathrm{G}}$

$\mathrm{Q}_{\mathrm{fN}}=0.5\left(\mathrm{~N}_{\mathrm{fU} 1}+\mathrm{N}_{\mathrm{fU} 2}+\mathrm{N}_{\mathrm{fL} 1}+\mathrm{N}_{\mathrm{fL} 2}\right) \sin \gamma$

:曲げ応力成分

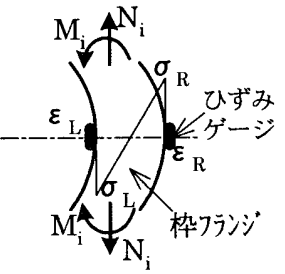

$\mathrm{M}_{\mathrm{i}}=\left(\sigma_{\mathrm{R}}-\sigma_{\mathrm{L}}\right) \cdot \mathrm{t}_{\mathrm{f}}^{2} \cdot \mathrm{b} / 12$

$\mathrm{N}_{\mathrm{i}}=\left(\sigma_{\mathrm{R}}+\sigma_{\mathrm{L}}\right) \cdot \mathrm{t}_{\mathrm{f}} \cdot \mathrm{b} / 2$

枠フランジ断面内応力分布は直線分布を仮定 $\sigma_{\mathrm{L}}, \sigma_{\mathrm{R}}:$ ひずみ $\left(\varepsilon_{\mathrm{L}}, \varepsilon_{\mathrm{R}}\right)$ からRamberg-Osgood モデルを適用して求めた縁応力

図 9 枠フランジ負担せん断力の算出方法

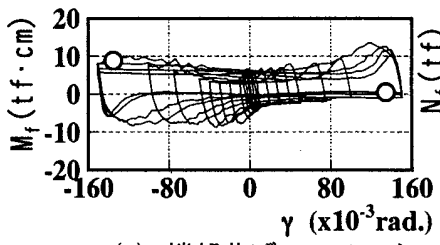

(a) 端部曲げモーメント

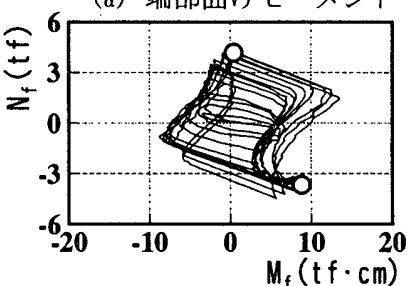

(c) 端部軸力ー曲げモーメント

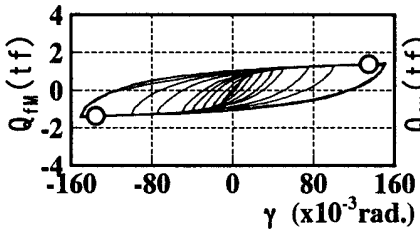

（d）曲げによる負担せん断力 [両フランジの合計 ]

図 10 枠フランジの端部応力、全負担せん断力の履歴 (L100-33 試験体の例)

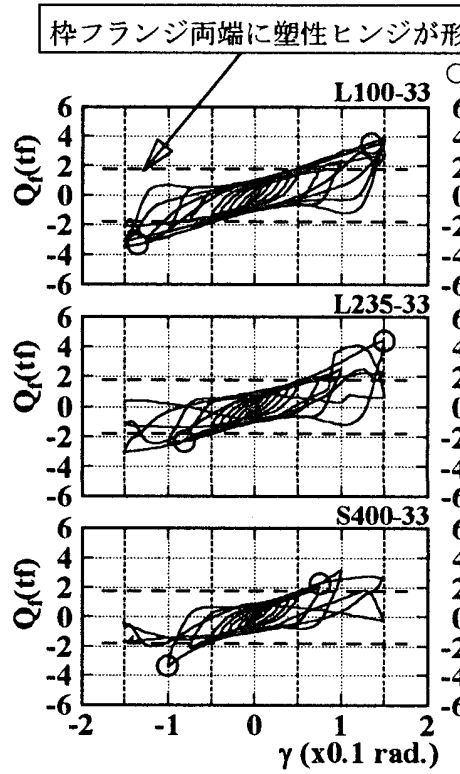

図 11 枠フランジ負担せん断力の合力とせん断変形角の関係

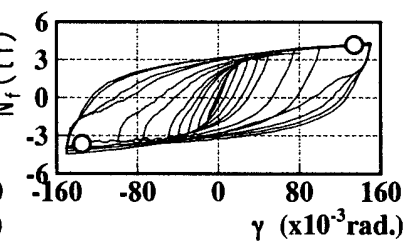

(b) 端部軸力

[ 記号の説明 ] $M_{f}:$ フランジ端部モーメント $\mathrm{N}_{\mathrm{f}}$ : フランジ端部軸力 Q フランジ負担せん断力 $Q_{\mathrm{fN}}:$ 軸力による フランジ負担せん断力 $\bigcirc$ ：最大荷重時 相関関係

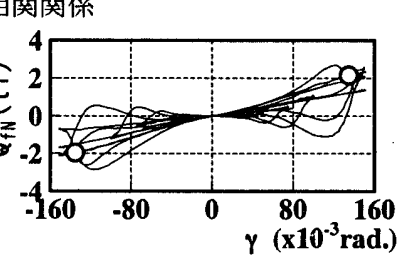

(e) 軸力による負担せん断力 [ 両フランジの合計 ] 形成された時の負担せん断力

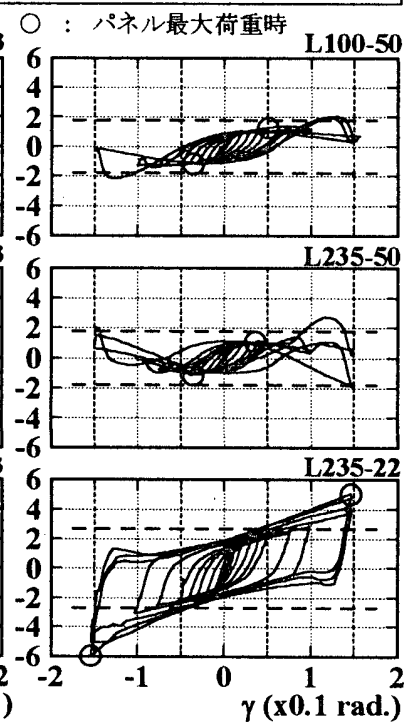


4.2 性能保証限界累積せん断変形角（変形能力 ）

もう一つの重要な履歴性能指標である性能保証限界累積せん断变 形角 ( 以下、限界累積変形角 ) は、前述したように; 履歴曲線上で 接線勾配がゼロとなる累積変形時としている。

このような性能保証限界変形（以下、限界変形）を設定する理 由は、以下の通りである。

(1) 性能保証の観点からは、測定可能である必要があり、累積变形は ラチェットの原理を利用した変位計により測定可能である。これは、 一方向の累積変形を測定するもので、その詳細は別報で示す。

(2) 履歴曲線上で接線勾配がゼロとなる時点は、複合応力下のパネル 部に余剩耐力・剛性が無い状態と見做すことができる。従って、こ れまでに実施してきた軸圧がゼロの条件下での実験デー夕収集範囲 内において、この変形を耐震設計上の性能保証限界変形とする。ま た、限界変形以降のエネルギー消費能力は余剩能力と見做すが、余 剩能力が大きいものほど安定であると判断している。

\section{(1) 既提案式による評価}

この限界累積变形角と換算幅厚比との関係を図 12 に示す。前記の パネル最大せん断応力度と同様に、図中の実線は文献 8)に示す極低 降伏点鋼正方形パネルダンパーに関する最小二乗近似の実験式であ る。また破線は実験式に対し士20\%の変動を考慮した值である。

幅厚比が最も小さい L235-22 試験体以外の試験体の実験結果は、 既実験式の結果とほぼ一致しており、換算幅厚比が、極低降伏点鋼 以外の鋼種のパネルダンパーに関する変形能力予測にも有効な評価 変数であることが確認された。なお、L235-22 試験体は溶接部が破 断したため、変形角が相対的に小さ目の值となっている。

\section{（2）性能保証限界変形時におけるパネルの面外撓み状況}

各サイクル最大変形時において、座屈に伴って生じるパネル中央 部の面外撓み量を図 4 (b)に示す変形測定法により測定した。同撓み 量をパネル内法せいで除して撓み角 $\left(\mathrm{R}_{\mathrm{p}}\right)$ に変換し、累積変形角 との関係にして、図 13 に示す。図中の、印は限界変形時の撓み角を 示している。

LYP100 と LYP235 の試験体について、幅厚比の違いによる撓み角 の履歴を比較すると、幅厚比の大きいものほど、小さな累積変形角 で面外撓み角が急増しはじめている。

幅厚比が等しい場合には、撓み角が急増する累積変形角は、降伏 点の高いもの（降伏比が大きいもの）ほどわずかに早く生じる傾向 が見られるものの、大略同じであった。

この実験結果において注目すべき点は、累積変形角時の撓み角が、 LYP100 では $80 \times 10^{-3} \mathrm{rad}$. 前後の值となるのに対し、LYP235、SS400 では、その約 $1 / 2$ の $40 \times 10^{-3} \mathrm{rad}$. 前後の值となっている点である。 詳細な考察は今後の課題とするが、伸び能力が高く降伏比が小さい LYP100 は、他の 2 つの鋼種に比してせん断座届を伴う大変形時にお いて安定性に富んだ履歴性能を有することが確認された。

\section{3 履歴特性のモデル化}

パネルダンパーの履歴特性を精度良くモデル化することは、耐震 設計上有益である。既報 ${ }^{8)}$ では、極低降伏点鐹パネルダンパーに対 し、孟・大井・高梨が提案しているスケルトン・シフト・モデル 101 の適合性が良いことを示した。その際、スケルトン曲線が幅厚比に よらず共通の包絡線を有することを確認し、そのモデル化を提示し た。

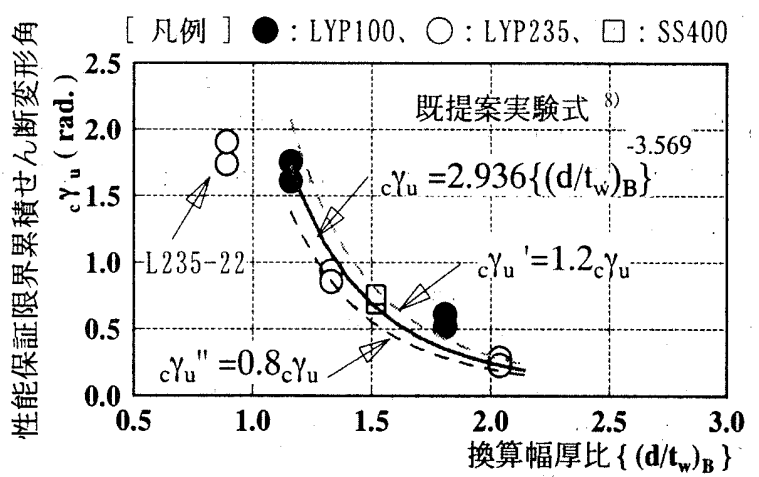

図 12 性能保証限界累積せん断変形角と換算幅厚比との関係

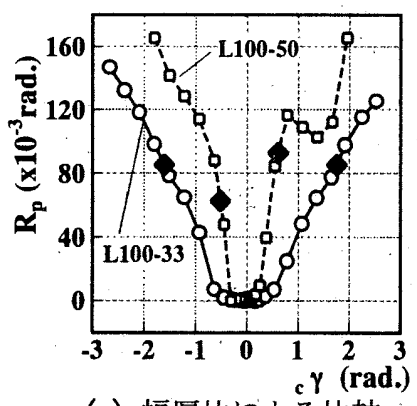

（a）幅厚比による比較 (LYP100試験体)

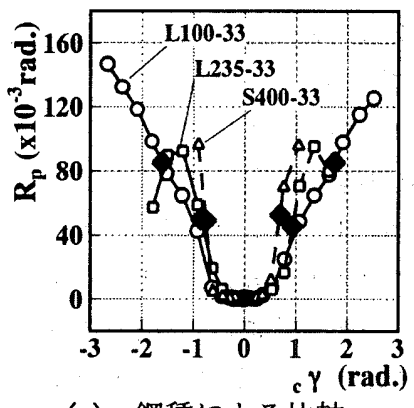

（c）鋼種による比較 (幅厚比：33試験体)

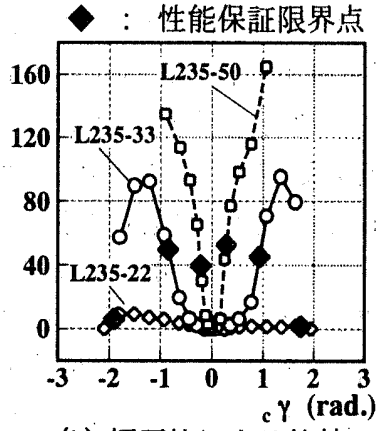

(b) 幅厚比による比較 (LYP235試験体)

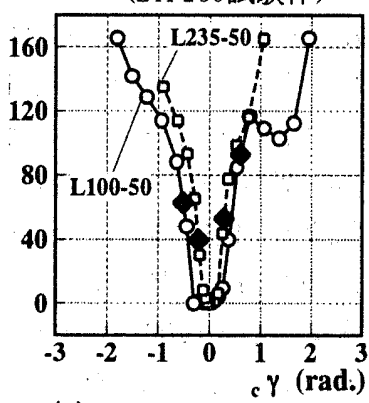

(d). 鋼種による比較 (幅厚比：50試験体)
図 13 パネル中央部面外撓みと累積せん断変形角との関係

以下には、他の 2 つの釦種に対しても同一の手法により、モデル 化を行った結果を示し、その有効性を検証する。

(1) スケルトン曲線

荷重一変形繰返し履歴曲線に対し、加藤・秋山モデル ${ }^{11}$ により得 られる最大荷重までの単調載荷時荷重一変形曲線に相当するスケル トシ部を求め、鋼種ごとに比較して、図 14 に示す。同図中には、後 述する各鋼種ごとのモデル化曲線を併記している。

図 14(a)，(b)には、それぞれ LYP100 とLYP235について、幅厚比 の違いによるスケルトン曲線を比較して示す。LYP235 には多少のば らつきが見られるが、両鋼種ともほぼ同一のスケルトン曲線上に実 験值が位置している。この結果は、文献 8)、12)に示される LYP100 に関する研究結果亡一致する。この事実は、履歴モデルを作成する 際に、鍓種別にスケルトン曲線を設定できる利点を示している。 次に、スケルトン曲線上の最大耐力点のせん断変形角と前記した 
換算幅厚比の関係を示したのが、図 15 である。両者の間には、図中 に示す良好な相関性がある。この相関関係と前記した最大耐力の推 定法と併用することにより、スケルトン曲線上の最大耐力点を、換算 幅厚比により精度良く予測することが可能である。

\section{(2) スケルトン曲線のモテル化}

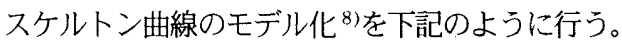

モデル化するスケルトン曲線は、図 16 に示すように、(1)降伏せん 断応力度までの線形域、(2)降伏後の小塑性ひずみ域、(3)ひずみ硬化 が明瞭となる大塑性ひずみ域および(4最大せん断耐力以降のひずみ 領域により構成する。図中のせん断応力度は、平均せん断応力度を 用いている。

大塑性ひずみ域の全ひずみ $(\gamma)$ と全応力 $\left(\tau_{\mathrm{w}}\right)$ との関係を式(2) に示すように、弾性ひずみ $\left(\gamma_{\mathrm{e}}\right)$ と塑性ひずみ $\left(\gamma_{\mathrm{p}}\right)$ の和とし、 $\gamma_{\mathrm{p}}$ を $\tau_{\mathrm{w}}$ のべき関数 ${ }^{13)}$ で表す。

$$
\gamma=\gamma_{e}+\gamma_{p}=\tau_{w} / G_{0}+\alpha \cdot \tau_{w}^{\beta}
$$

以上の設定のもとに、まず実験で得られた各試験体のスケルトン曲 線に対し、(1)初期剛性（ $G_{0} ）$ は公称值とし、降伏応力度 $\left(\tau_{w y}\right)$ は 素材試験結果をもとに、Von-Mises の降伏条件を用いて求める。次 に、(3)大塑性ひずみ域 $\left(\gamma_{\mathrm{po}} \leqq \gamma \leqq \gamma_{\mathrm{u}}\right)$ での $\gamma_{\mathrm{p}}-\tau_{\mathrm{w}}$ 関係の係数 $\{$ 式 (2)右辺第 2 項の $\alpha$ と $\beta\}$ と同ひずみ域の開始ひずみ $\left(\gamma_{\mathrm{po}}\right)$ を、両 対数軸上で求める。具体的には、 $\gamma_{\mathrm{po}}$ は両対数軸上で $\gamma-\tau_{\mathrm{w}}$ 関係が 線形になり始める点のひずみである。そして(2)小塑性ひずみ域 $\left(\gamma_{\mathrm{y}}\right.$ $\leqq \gamma \leqq \gamma_{\mathrm{po}}$ ）の応力ーひずみ関係を直線式により補間して求める。最 後に、(4)換算幅厚比に応じて算定した最大せん断耐力を平均せん断 応力度に変換し、 $\tau_{\mathrm{wu}}$ として定め、以降は勾配ゼロの直線とする。 以上手順により、陽な形ではないが、幅厚比に応じたスケルトン曲 線のモデル化曲線が得られる。各鋼種毎に得られた結果の平均值を 一覧にして表4に示す。モデル化曲線と実験值を比較して図 14 中に 示す。

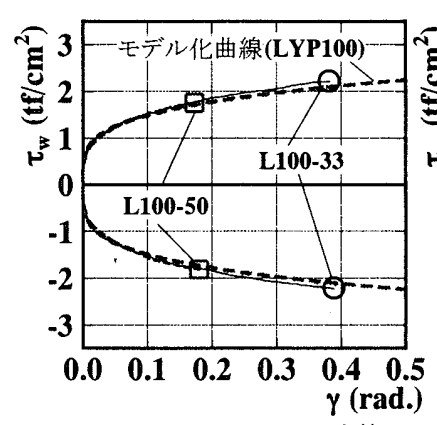

(a) LYP100試験体

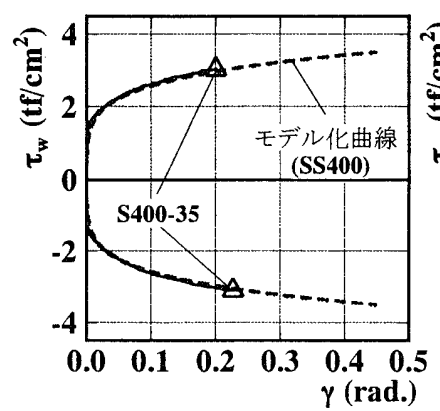

(c) SS400試験体

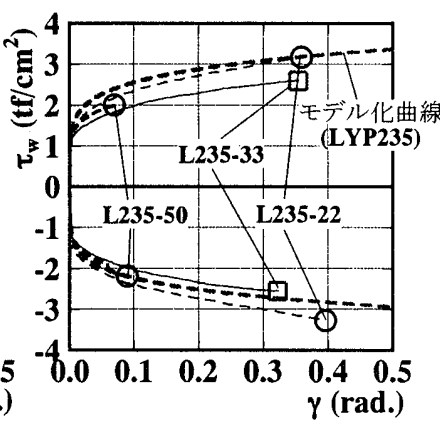

(b) LYP 235試験体

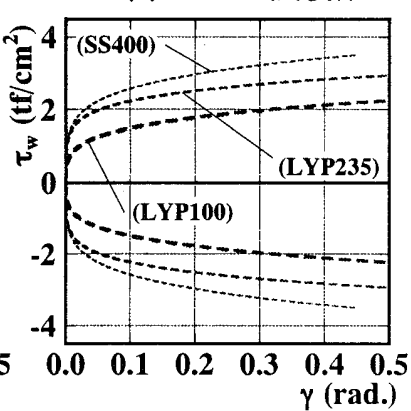

（d）モデル化曲線の比較

図 14 鋼種每のスケルトン曲線の比較(実験値と計算值の比較)

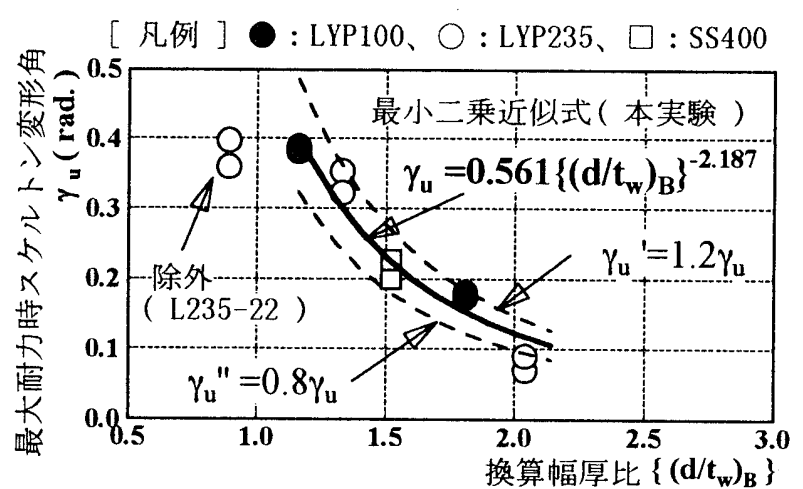

図 15 最大耐力時のスケルトン曲線のせん断変形角と 換算幅厚比との関係

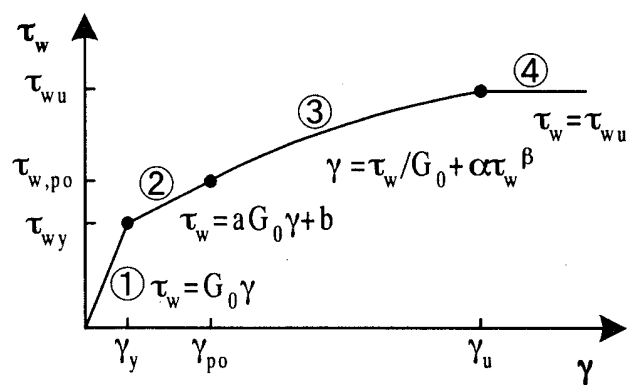

図 16 スケルトン曲線のモデル化

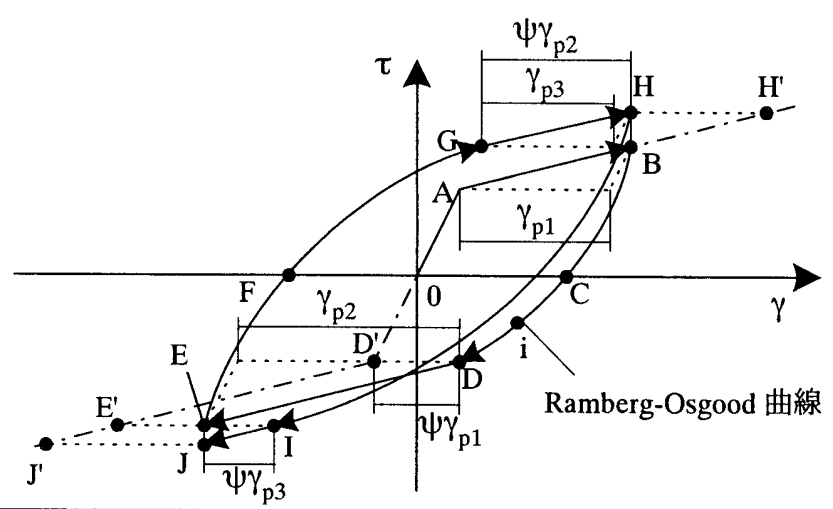

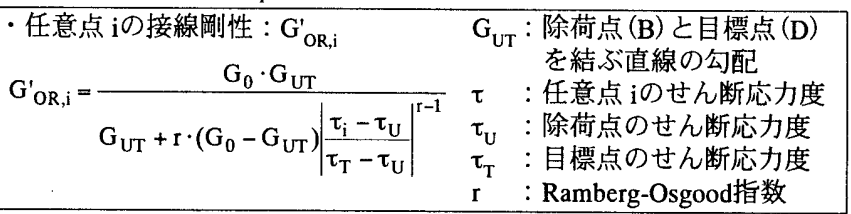

図 17 スケルトンシフトモデルのルールの概要

(3) 履歴モデル

スケルトン・シフト・モデルの履歴ルールの概要を図 17 に示す。 履歴特性を規定するパラメー夕は、Ramberg-0sgood 指数（r ）と除 荷時の目標点（ シフト量）を定める係数（ $\Psi)$ である。目算に よる試行錯誤により求めた、各試験体共通に適合性が良い上記 2 パ ラメータの平均値を、表 4 中に示す。 $\mathrm{r}$ の值は各鋼種共に 10 となつ

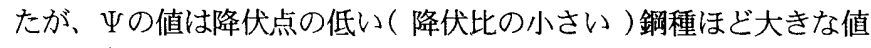
を示した。

なお、既報 8)に示した両係数の值は本報と異なつている。その理 由は、シフト量の対象とすべき塑性変形量を、直前の正負最大変形 点から推定される全塑性変形量（図 17 中の $\mathrm{C}-\mathrm{F}$ 間）としていた ためである。結果的には、本報のモデル化の方が実験結果により適 合するので、以降は本モデルを採用するものとする。本モデルは、 
表4 履歴モデルの鋼種別パラメーター一覧

\begin{tabular}{|c|c|c|c|c|c|c|c|c|c|c|c|}
\hline パネル鋼種 & $\mathrm{G}_{0}$ & $\mathrm{a}$ & $\mathrm{b}$ & $\alpha$ & $\beta$ & $\tau_{\mathrm{y}}\left(\mathrm{tf} / \mathrm{cm}^{2}\right)$ & $\tau_{\mathrm{po}}\left(\mathrm{tf} / \mathrm{cm}^{2}\right)$ & $\gamma_{\mathrm{y}}(\mathrm{rad})$. & $\gamma_{\mathrm{po}}(\mathrm{rad})$. & $\psi$ & $\mathrm{r}$ \\
\hline LYP100 & 810 & 0.0491 & 0.475 & 0.0200 & 3.98 & 0.50 & 0.67 & 0.00062 & 0.0048 & 0.80 & 10 \\
\hline LYP235 & 810 & 0.0213 & 1.333 & 0.000845 & 5.91 & 1.36 & 1.64 & 0.00168 & 0.0178 & 0.70 & 10 \\
\hline SS400 & 810 & 0.0194 & 1.535 & 0.000866 & 4.98 & 1.57 & 1.96 & 0.00193 & 0.0270 & 0.65 & 10 \\
\hline
\end{tabular}

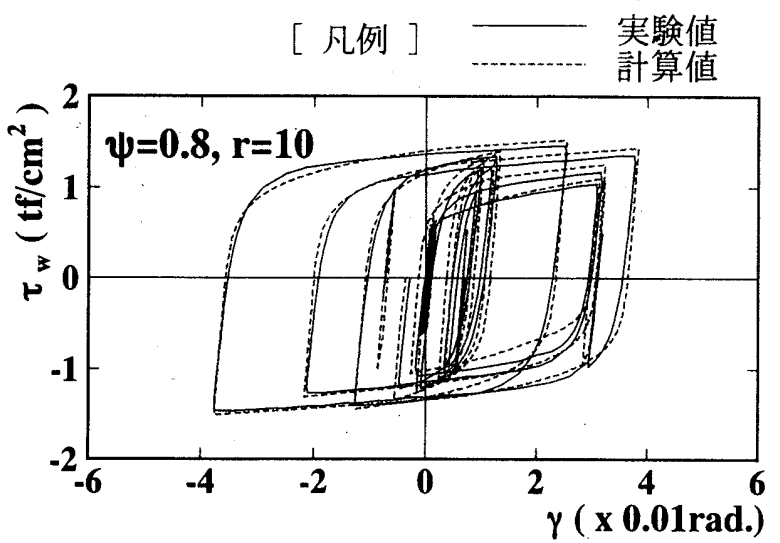

図 18 任意変形履歴(既実験值)に対する本履歴モデルの適応状況 （試験体は文献 8）に示す “L4RR385-2 試験体”で、El Centro 1940 NS ”地震動に対する変形応答を変形制御で実験）

任意の履歴に対しても十分妥当な結果が得られることは図 18 に示す 通りである。なお、その適用範囲は前記した性能保証限界変形まで である。

\section{(4) 実䁐結果との比較}

以上の履歴モデル計算值（性能保証限界変形点まで）と実験結 果を比較して、図 5 中に示す。各試験体共に計算值は実験值に良く 対応している。この結果より、他の 2 つの鋼種に対しても、極低降 伏点鋼に対して得られたモデル化を適用できることが確認された。

\section{5. まとめ}

3 種類の鋼種（LYP100、LYP235、SS400）を用いたせん断型パネ ルダンパーに関する軸力ゼロ下での静的繰返しせん断実験結果およ び考察結果より、本実験範囲内における以下の知見を得た。

（1）各鋼種ともに、幅厚比および必要エネルギー消費量を適切に選 定すれば、ダンパーとしての適性が認められた。しかし、幅厚比が 同じ場合、エネルギ一消費能力は、パネル素材の変形能力に依存す るため、降伏比が小さく伸び能力のある LYP100 が最も高くなる結果 を示した。

（2）パネル部の最大せん断応力度は、極低降伏点鋼パネルダンパー に対し既に得ている実験式により、鋼種が異なっても同様に予測で き、また評価変数として式(1)に示す換算幅厚比が有効であることが 確認された。

（3）性能保証限界累積せん断変形角も、換算幅厚比を用いた既実験 式により、最大せん断応力度と同様に予測できることが確認された。

（4）試験体数は少ないが、2 種類の鋼種（LYP100、LYP235 )につい て、幅厚比が変化してもスケルトン曲線は共通の包絡線を有する結 果を得た。またスケルトン曲線上の最大耐力点のひずみは、換算幅 厚比との相関性が強いことを確認し、近似的実験式を得た。
（5）１つの鋼種に 1 組のパラメーターで設定できる鋼種別スケルト ン曲線のモデル化を行った。またスケルトン・シフト・モデルにより、 各鋼種ともに履歴特性を精度良く表すことができることを確認した。

\section{謝 辞}

本実験を行うに際しまた本論文作成に際し、(株) フジ夕技術研究 所構造研究部関係各位の協力を得た。また新日本製鐵（株）の池辺卓 氏と山口種美氏の協力を得た。記して謝意を表します。

また本論文に対し、貴重なご意見を戴いた東京大学小谷俊介教授 と東京工業大学和田章教授に謝意を表します。

\section{参考文献}

1）玉井宏章，竹中繁之，中野孝司，小島 修，近藤一夫，花井正実：低 降伏応力度鋼板を用いた $K$ 型ブレ一ス制振装置に関する研究（その 1２）, 日本建築学会大会学術講演梗概集 (東北), pp. 1447-1450, 1991 年 9 月.

2）泉 満，可览長英，成原弘之，小倉桂治，川又康博，紐沢 治: 極低 降伏点鋼を用いたせん断降伏型制振部材の低サイクル疲労実験（そ の1，2）, 日本建筑学会大会学術講演梗概集 (北陸), pp. 1333-1336, 1992 年 8 月.

3）佐分利和宏, 岩田 衛, 中島正愛, 許斐信三, 岩井 哲, 赤沢隆士： 低降伏点鋼を用いた鋼板パネルの履歴性能, 日本建築学会大会学術 講演梗概集(東海)，pp. 1341-1342，1994 年 9 月.

4）三山剛史，田中 清，孟 令桙，平澤光春：極低降伏点鋼を用いた制 振構造に関する研究（その 3，4），日本建築学会大会学術講演梗概 集(東海), pp. 1043-1046, 1994 年 9 月.

5）品部祐児, 高橋泰彦: せん断抵抗型耐震要素の復元力特性のモデル 化に関する実験的研究（その 1，2），日本建築学会大会学術講演梗 概集 (北海道)，pp. 469-472，1995 年 8 月.

6）金澤 寛，古賀洋行，玉井宏章，近藤一夫，花井正実，江口 清，藤 波健剛，山䗁達司：普通鋼を用いた制振ブレースエネルギー吸収部 材の開発（その 1，2），日本建築学会大会学術講演梗概集 (近畿), pp. $769-772,1996$ 年 9 月.

7）計良光一郎, 山口種美 : 弾塑性ダンパー／低降伏点鋼・極低降伏点 鋼, 日本建築学会近畿支部陑震研究部会シンポジウム, pp. 1-9,1993 年 12 月.

8）田中 清，佐々木康人：極低降伏点鋼を用いた制震パネルダンパーの 静的履歷減衰特性に関する研究，日本建築学会構造系論文報告集, 第 509 号, pp. 159-166，1998 年 7 月.

9）田中 清, 佐々木康人, 米山真一朗 : 鋼種が異なるせん断型パネルダ ンパーの静的履歴特性に関する実験研究（その 1，2），日本建築学 会大会学術講演梗概集 (九州)，pp. 815-818，1998 年 9 月.

10）孟 令樺，大井謙一，高梨晃一：鉄骨骨組地震応答解析のための耐力 劣化を伴う簡易部材モデル, 日本建築学会構造系論文報告集 第 437 号, pp. 115-124, 1992 年 7 月.

11) Kato, B. and Akiyama, H. : Inelastic Bar Subjected to Thrust and cyclic Bending, Proc. of ASCE, Vol. 95, ST1, Jan., 1969.

12）川又康博，泉 満，成原弘之：極低降伏点鋼を用いたせん断降伏型制 振部材の低サイクル疲労実験（その $5:$ 極低降伏点鋼のせん断応力 一せん断ひずみ関係の数式モデル），日本建築学会大会学術講演梗 概集(東海)，'pp. 1099-1100，1994 年 9 月.

13）佐伯英一郎，杉沢 充，山口種美，望月晴雄，和田 章: 低降伏点鋼 のヒステリシス及びヒステリシスエネルギー特性に関する研究，日 本建築学会構造系論文報告集，第 473 号，pp. 159-168，1995 年 7 月. 